\title{
The Needs of Functional Academic Teaching Materials for Special Education Teachers With Visual Impairment
}

\author{
Sayidatul Maslahah* \\ Special Education \\ Graduate School \\ Universitas Negeri Yogyakarta \\ Yogyakarta, Indonesia \\ Sayidatulmaslahah@gmail.com*
}

\author{
Mumpuniarti Mumpuniarti \\ Special Education \\ Faculty of Education \\ Universitas Negeri Yogyakarta \\ Yogyakarta, Indonesia \\ mumpuni@uny.ac.id
}

\author{
Ishartiwi Ishartiwi \\ Special Education \\ Graduate School \\ Universitas Negeri Yogyakarta \\ Yogyakarta, Indonesia \\ buisyk@yahoo.com
}

\begin{abstract}
Functional academic learning is crucial for students with visual impairment, since it is a basis for problem solving in life. This learning aims to increase students' independence in daily life. The purpose of this study was to determine the needs of functional academic teaching materials for special teachers of students with visual impairment. The research implemented descriptive qualitative method. The subjects of this study were teachers at one of SLB for the students with visual impairment in Yogyakarta. Data collection was conducted in this study by using observation, interview, and documentation techniques. The data was analyzed by using qualitative descriptive analysis techniques. The results of the study showed that the special teachers of students with visual impairment require functional academic teaching materials that are more organized and systematic based on the learning stages with the syntax of contextual learning models. Good teaching materials should have brief, communicative, solid, and systematic language use. The scope of the content contained in teaching material should be suitable with the students' conditions as the learning subjects.
\end{abstract}

Keywords- functional academic, teaching materials, teacher, students with visual impairment

\section{INTRODUCTION}

Functional academic is a very important learning for children with special needs, such as students with visual impairment and intellectual disability. The use of symbols or information coding that are concrete and can be found in daily life is necessary [1]. The visually impaired person is someone who experiences visual impairment and experiences $85 \%$ loss of visual perception [2]. The learning characteristics of the students with visual impairment and intellectual disabilities must use concrete and functional knowledge [3]. Also, [4] Vygotsky believes that concrete things are necessary in teaching process. In addition, the appropriate guidance is necessary for training the students, in order to make them more independent in living their lives [5]. One of the roles needed in the learning process is the teacher's role. The teacher can provide learning by organizing the learning activities like the real daily lives [6].
The teacher becomes an important component in the success of this implementation.

Special education teachers are educators who provide instructional guidances for students with special needs [7]. For example, the teacher of students with visual impairment also has a role as a learning provider for reading and writing Braille appropriately [8]. A teacher must have Braille literacy skills [9]. The adaptive process of communication and teaching requires teachers who are willing to meet the parents and the students as their partners. [10]. Teachers and students must be equally active. The teacher is not the one who determines the learning, but rather comes from the students themselves [11]. Therefore, the teacher plays a very important role for helping students in gaining new knowledge.

A teacher will be helped if the teaching materials are appropriately used. [12] shows that the selection of relevant teaching materials and the teachers' ability to improvise in learning have a significant impact on functional academic learning. Students' independence is seen from their ability to perform mobility and self-determination in relation to work, school, recreation, and daily activities [13]. By relating to the experience, students will construct their own understanding of the world around them [11]. Based on the constructivism theory, learning is a process of building meaning and how people understand their experiences related to the real life [14].

Environmental influences, gestures, encouragement, and learning model need to be provided as the facilities in learning activities. [15] Piaget stated that learning does not occur passively, but occurs actively and meaningfully. One of the learning processes needed by the teacher is to provide teaching materials.

Learning material is used by the students in order to study more effectively [16]. The contents of teaching materials are those which needed by the students in printed form and facilitated by the instructor to achieve the learning objectives [17]. They appear in the programs which are arranged in a particular form based on the learning interest. [18]. Teaching materials can be used if the product's quality is good. Criteria for good teaching materials [19] include the 
feasibility of content, the feasibility of linguistic aspects, the feasibility of presentation, and the feasibility of graphics. Teaching materials should prioritize those criterions in order to make good teaching materials.

However, there are several problems that occur in the learning process at school. One of them is sometimes begun to invite children to go to the market. The learning process still uses a lecture method that causes students to be passive and tend to be the knowledge recipients only. In addition, functional academic teaching materials have not been conducted yet. Based on preliminary studies in one of the SLB-A for blind people in Yogyakarta, the data shows that there has been no teaching material that is well summarized until now. On the other words, the curriculum is also on average or still modify the general elementary school curriculum. The teacher said that until now there has been no systematic learning about functional academics. Therefore, this research can be an initial step for collecting information in establishing empirical and theoretical conditions (needs analysis) to design functional academic teaching materials. From the result of the preliminary study, it can be seen that the needs in the real condition can be a basis for preparing functional academic teaching materials.

Hence, the purpose of this study was to determine the needs of functional academic teaching materials for special teachers of students with visual impairment. It was conducted because of the interest in developing teaching materials based on the criteria.

\section{METHODS}

This study implemented a qualitative approach by using descriptive research. The purpose of this study was to describe various conditions, situations, or social phenomena that occur in society [20]. The purpose of this study is to describe the needs of teaching materials for teachers in SLB A Yaketunis.

This research was conducted at SLB A Yaketunis which is located at Jalan Parangtritis No 46 Danunegaran Yogyakarta. The setting of this research was in the school, by observing the learning activities periodically. In order to support this research, the data were obtained through these followings: (1)Observation, this technique was implemented by researchers to observe learning activities in SLB A Yaketunis; (2) Interview, this technique was implemented to directly interview the implementation of learning activities in SLB A Yaketunis which contribute to the research object; (3) Documentation, the researcher documented the learning activities in SLB A Yaketunis.

The data analysis technique used in this study was a qualitative descriptive analysis technique. Qualitative data analysis is an effort made by examining through data, compiling data, choosing what can be managed, looking for themes and finding patterns, finding important things that are necessary, and can be explained to others [21]. The stages in this study included data collection, data condensation, data presentation, and drawing conclusions [22].

\section{RESULT AND DISCUSSION}

Result

The results were obtained based on the observations and interviews with the teachers at SLB A Yaketunis and analysis of students' textbook published by the Indonesian Ministry of Education and Culture, based on Kurikulum 2013. The research began with examining the needs during the learning process at SLB A. Based on the results of interviews with SLB teachers, it was found that the teacher still had difficulties in developing students' abilities related to their knowledge and skills in using functional academics in daily life, especially for students with visual impairment. Data were obtained during the literature study on core competences and standard competence on the curriculum of SLB A 2013 textbook and related literature about the implementation of functional academic material, which can be explained as follows: material on functional academic implementation was not very brief but there were already several subjects that integrated such as the introduction of money; the use of money is based on the students with visual impairment needs in their daily lives; concern with the skills of adaptive behaviors for the students with visual impairment when using money. This curriculum is prioritized for activity-based programs. Students' schedules are organized around daily activities based on their age and prepared for the students in order to have productive life in the future, combined with traditional academic with real-life tasks.

The process of obtaining information about functional academic learning for visually impaired students also experiences difficulties since the special book is not available. So far, they just listen to the teacher's lectures which makes the acquisition of information is less than the maximum. In addition, it was mentioned that these students are in a concrete operational cognitive stage. Piaget said that a child is in the concrete cognitive operational stages of 7 / 11-11 / 12 years old (elementary school). At this stage, the children begin to use something with logical thinking or using concrete or real things [23].

Based on the lectures that are delivered by the teachers in class, they are still experiencing difficulties due to various factors such as lack of formulation of learning about functional academics in a systematic and structured manner. Thus, what the teacher should do is to modify the curriculum based on the elementary curriculum.

Functional academic learning is still not systematically structured in terms of material, curriculum, and learning process. Hence, the teachers still have difficulty in learning functional academic which want to be applied to the students with visual impairment. Meanwhile, what blind students are need is the learning which is suitable with the real life since it contirbutes to the independence in social life.

The process of obtaining information for students with visual impairment are not similar with other people in general. They lose their vision, which is the largest information acquisition owned by humans, as much as $85 \%$. The students with visual impairment have difficulty in obtaining a stimulus that comes from their vision. Therefore, stimulation from the rest of the senses are necessary such as 
touching and hearing. Hence, in the learning process, the students are expected to to take advantage of concrete or real-life learning strategies since it will be more optimal for obtaining the information. Stimulus should be given to the students maximally, since it will make the process of perception and sensation be successfully captured and responded by the brain properly.

The interview results with SLB teachers indicated that teachers want a more organized and systematic textbook or teaching materials in order to help students in learning about functional academic implementation in daily life. Media and learning resources can be considered as qualified if they can create meaningful learning experiences, in order to be able to facilitate the interaction between students and teachers, students with each other, students with relevant experts, and the environment; can enrich the learning experience; as well as being able to change the learning from passive learners and teachers as the only source of knowledge, become active students who discuss and explore the knowledge by seeking information and experiences through various sources and objects [24].

It occurs since learning is a process of improving mental trust through the active interaction of individuals with their environment in order to provide changes in knowledge, skills, attitudes and values. This material should include knowledge, skills, and attitudes aspects. This teaching material is prepared with several variations such as pictorial and Braille. The teacher hopes that materials in the book must be concise and use simple sentences but clear, supported by pictures. The pictures should be colored and presented clearly. The chosen font / letter form can be read clearly by the students with visual impairment. Based on the cover, it is presented with colored pictures and letters in order to attracts the students' interest when reading.

\section{Discussion}

Based on the results, it was found that functional academic teaching materials had not been available yet. According to the teachers, even it was still modifying the curriculum for public elementary schools, and make the teacher have difficulties. Based on the data during the literature study of core competeces and standard competences, the SLB A textbook and related literature, especially the implementation of functional academic material, there is no assessment of the material. Meanwhile, good material should have certain criteria.

The applied curriculum should prioritize the materials based on the experiences and activities, since it can make students more participated in the deep learning process. Learning is also an effort of students to give meaning to their experiences that lead to the development of cognitive structures independently and socially [25].This curriculum is prioritized an activity-based programs. Student learning is organized based on the daily activities. The application of the contextual learning can improve the motivation, active participation, improve a conducive learning atmosphere, interesting and fun, students are easier to understand and master the competencies in order to make the learning becomes more meaningful. [26].In line with this opinion, the curriculum given to students must also prioritize the current stages of students' thinking skills. Students with visual impairment as the subjects are in the concrete operational cognitive stages. Piaget said that children which are in the concrete cognitive operational stages consist of 7 / 8-11 / 12 years old children (elementary school). At this stage, children begin to use something with logical thinking by using things that are concrete or real [23].A good curriculum modification process will also affect the learning process in the classroom. Therefore, learning assistance is needed by the teacher by using teaching materials that have been arranged in a systematic, solid, brief, and easy to use.

The importance of studying functional academics for students with visual impairment is because the materials with daily acitivies are used for their independence in social life. One of the learning methods that can be implemented is functional academics. Bouck and Joshi define functional academics as an approach to teach students everyday life skills to adapt to society an approach to teach students several daily life skills in order to adapt with society [27]. In addition, functional academics is one part of the functional curriculum designed for teachers in teaching basic skills for students starting from kindergarden until second grade [28].

Functional academic is a course which aims to use simbols or codes towards the environment [1]. Functional reading is an activity of reading about things in daily life, functional writing is a writing activitiy that is directly applied in daily life and functional mathematics. This functional mathematics uses the principles of realistic mathematics learning. This realistic mathematics learning utilizes the reality and environment that students understand in order to facilitate the process of learning mathematics in real / concrete things. Teaching and learning Realistic Mathematics has criteria especially for the experience in students' daily life. Mathematics is applied in solving daily problems [29].

The process of perception of students with visual impairment is not different from other students, but only differs in the modality [30]. Also, the perception can be obtained from the stimulus [31]. The process of obtaining this stimulus consists of 2 stages, such as the sensation stage and the perception stage. In addition, in daily life, the people with visual impairment rely more on hearing information [32]. They can process the acquired language faster by using auditory system which also can be used as the compensation for losing sense of sight. People with visual impairment can acquire the information better, for example when acquiring skills for perceptual hearing, such as discriminating tone or duration, and when hearing language and memory. It occurs since in daily life, there are many activities that involve more than one sensory system. Based on previous studies, they had proved that the use of multysensory can integrate information across modalities which capable to facilitate perception and control their actions. Therefore, the students with visual impairment can get complete information based on the stimulation.

In this research, the researchers conducted needs analysis in order to determine the teaching materials users, teachers or students. Functional academic learning is very important to be taught to students with visual impairments. 
It refers to visual obstacle that interferes with the learning process optimally based on the required methods, the coherence of learning materials, and learning environment [33].

The next analysis is the map of standard competencies and basic competencies according to the applied curriculum, based on the students' development stage. Next is the analysis of learning resources by inventorying the availability of learning resources around the user. Components of the curriculum that contains information are in the form of principles or rules, concepts, facts, procedures, problems, which are arranged systematically in order to achieve the students' competence [34]. In addition, it was also conveyed by Dick, Carey \& Carey who said that the content of teaching materials are needed to be learned by students in printed form and facilitated by the instructor in order to to achieve the learning objectives [34].

For examples, teachers can teach students to shop, teachers can arrange classes by arranging tables and chairs like a market and using photos of food, vegetables, fruit, that are sold, then students can practice buying and selling in the classroom. These activities can be even better if using concrete items, such as real food or real money. Functional academic learning for can be conducted if it is supported by the school curriculum. A curriculum has a learning plans that directly to the teacher in order to have personal readiness and abilities according to the societies' needs [35].

When finding an experience or situation that challenges the way of thinking, then imbalance is created. Conditions for changing students must change their thinking skills in order to get balance. It is intended that students learn to understand new information and then relate it to knowledge that has been previously known. In order to make the materials and programs become directed, they need to be arranged systematically and structured in order to make it easy to learn. On the other words, to obtain the truth of a concept of knowledge in one whole unit.

Aspects that need to be considered in developing teaching materials are users' characteristics, competency objectives, material coverage, assessment tools and revisions. These aspects are made by researchers as an anticipatory step in the development of teaching material content. Researchers analyze the needs of special education teachers in learning subjects according to the basic competencies of students with visual impairment. The basic competency objectives and scope of the material are written in the content of teaching materials in order to make it easy to learn. Teaching materials are also equipped with measurement tests for each grade level in written form. This is in line with teaching materials that should be arranged systematically and structured in order to make it easy to learn and the construction of the truth of a concept of knowledge in a unified whole [18]

The teacher wants a hand out or a textbook about functional academic learning that will be applied during the learning process, that can be learned easily. It includes the ease to understand the procedures for reading, writing and applying mathematics. The teacher suggests that a guidebook should also be available to find out the procedures and how to use a concise material with explanatory pictures. The contents of the book are expected to provide a display of how to write and read, and a coherent application of mathematics.

Each explanation is supported by examples of writing and reading making, in order to make it easier for teachers to explain functional academic learning. In addition, teaching materials can be used if they require the good product quality. Hence, the teaching materials should be developed based on certain criteria. The criteria for good teaching materials are the feasibility of content, the feasibility of linguistic aspects, the feasibility of presentation and, the feasibility of graphics. [19]

According to the interview results, the teacher hopes that the teaching materials should contain language use that is clear, communicative, solid, and systematic. The content in teaching materials should also suitable with students; condition. In addition, one material should relate with another material. This is in line with Suparman [36], Supriyadi [37], Dar [38] and Ronghua \& Stanley [39] who state: "Contains instructional objectives clearly, Contents are appropriate for the students' need, the contents are appropriare based on the field, the contents are up-to-date in terms of theory and examples, the description is systematic, logical and easy to understand, uses varied media and methods, the quotations are original, the contents are strengthened by research results, the exercises are varied, and nased on the instructional achievement, the tests are valid and reliable. "The criteria for teaching materials requested by teachers in SLB are also in line with Harjanto opiions as the criteria for instructional objectives: a selected subject material is intended to achieve the learning objectives [40]. In addition, subject matter should also correlate with one another, which is closely related to the specifications of the objectives and subject matter that can be observed and measured. And relevant to the students needs, each subject material is presented with efforts to develop students' personalities. Based on the conditins in the society, the material should help them provide educational experiences that are meaningful for their development into human beings which adaptable. The subject matter contains ethical aspects. The subject matter is arranged in a systematic and logical scope and sequence. The material is arranged sequentially by considering the students' psychological development factors. The subject material is adapted from standard books, expert teachers, and the community.

This teaching material must also prioritize aspects of learning for students with visual impairments, through the sense of touch and hearing. Hence, all criteria in the preparation of teaching materials must be suitable with the students with visual impairment learning needs. This is consistent with the opinion of Hallahan, Kauffman \& Pullen which states that learning for students with visual impairment is accompanied by intellectual and instruction nased on the real life settings with concrete materials [6]. The teacher can arrange the class activities as in daily lives, for example the teacher can teach students to shop. Functional academic contribution is media which uses symbols or encoding of the environmental phenomena. The role contained in functional academics is also suitable with its contribution in daily life. 


\section{CONCLUSION}

Based on the results and the above explanation, the conclusion is that the special teacher for students with visual impairment needs functional instructional materials that are more organized and systematic, and suitable with the learning process stages, with the syntax of contextual learning models. Teaching materials should be taught by using brief, communicative, concise, and systematic language. The contents in teaching materials should also be suitable with the students' condition in learning process. In addition, one material should be related with another material.

\section{ACKNOWLEDGMENT}

The author would like to thank RISTEKDIKTI for supporting this Research. The author also thanks the supervisor who has given motivation, enthusiasm, and guidance in completing this research and article. Then, the authors also thank the school staffs and teachers who have given permission in collecting the data. Also, to the team who have helped each other in arranging this article.

\section{REFERENCES}

[1] Mumpuniarti \& Pujaningsih. Pembelajaran Akademik Fungsional dalam Konteks Pendidikan Khusus Orientasi Budaya. Yogyakarta: UNY Press. 2016.

[2] Rudiyati, Sari. Pendidikan Anak Tunanetra. Yogyakarta: FIP UNY. 2002.

3] Salekin, L.K., Olley G.J., \& Hedge. A.H. Offenders with Intellectua Disability: Characteristics, Prevalence, and Issues in Forensic Assessment, Journal of Mental Health Research in Intellectual Disability, Vol.3 pp 97-116. 2010.

[4] Vygotsky. Mind in Society. Cambridge,M.A: Harvard University Press. 1978

[5] Smith, M.K. (2010). Teori Pembelajaran dan Pengajaran. Jogjakarta: Mirza Media Pustaka. 2010.

[6] Hallahan, D. P.; Kauffman, J.F; \& Pullen P.C. Exceptional LearnersCetakan ke-11. United State: Pearson. 2009.

[7] Lewis, R.B \& Doorlag, D.H. (Teaching Student With Special Needs in General Education Classrooms. USA: Pearson. 2011.

[8] Rudiyati, Pembelajaran Membaca dan Menulis Braille Permulaan Pada Anak Tunanetra. Jurnal. Jurnal Asesmen dan Intervensi Anak Berkebutuhan Khusus, Volume 9 Nomor 1 Juni. 2010.

9] Puttman, B \& Tiger, F. Teaching Braille Lettes, Numerals, Punctuation and Contractions to Sighted Indiiduals. Jurnal. Journal of Applied Behaviour Analysis; Summer 2015; 48, 2: ProQuest. 2015.

[10] Schuman, Hans. Segregation and the Transition to Adulthood for Student with a Visual Impairment. Fontys University of Applied Sciences Head of Research Group Interdiciplinary Collaboration. (TT).

[11] Schunk, D.H \& Meece, J.L. Motivation in Education: Theory, Research and Application Third Edition. New Jersey: Pearson. 2010.

[12] Ogaga, G. A. Igori Wallace and Egbodo Benson, A. Effects of Instructional Materials On The Teaching And Learning Of Social Studies In Secondary Schools In Oju Local Government Area Of Benue State. International Journal of Current Research Vol. 8, Issue, 07, pp.33859- 33863, July, ISSN: 0975-833X. 2016.

[13] Wehmeyer, Kelchner \& Richard. Essential Characteristics of selfdetermined behavior of indidviduals with mental retardation. American Journal on Mental Retardation.100, 632-642. 2011.

[14] Ormrod, J.E. Human Learning (6th ed). Unites States of America:Pearson. 2012.
[15] Piaget, J. The Construction of Reality in the Child. United States of America: Ballantine Books. 1974.

[16] Donald C.S \& Nkosha, P. Teaching and Learning Materials Analysisi and Development in Basic Education. Paris: UNESCO. 2008.

[17] Dick, Carey, \& Carey. The Systematic Design of Instruction, Seventh Edition. USA: Pearson.161. 2009.

[18] Susilana, Rudi dan Riyana, Cepi. Media Pembelajaran Hakikat, Pengembangan, Pemanfaatan dan Penilaian. Bandung: UPI. 2008.

[19] Widodo, Chomsin. Panduan Menyusun Bahan Ajar Berbasis Kompetensi. Jakarta: PT. Elex Media Komutindo. 2008.

[20] Bungin, Burhan. Metodologi Penelitian Kuantitatif. Jakarta. Kencana Prenada Media Group. 2010

[21] Moleong, Lexy. Metodologi Penelitian Kualitatif. Bandung: PT. Remaja Rosdakarya. 2007.

[22] Miles, M.B, Huberman, A.M, dan Saldana,J. Qualitative Data Analysis, A Methods Sourcebook, Edition 3. USA: Sage Publications. Terjemahan Tjetjep Rohindi Rohidi, UI-Press. 2014.

[23] Piaget, Jean \& Barbel Inhelder. Psikologi Anak. Terj. Miftahul Jannah, Yogyakarta: Pustaka Pelajar. 2010.

[24] Niron, Budiningsih \& Pujiriyanto. Rujukan Integratif Dalam Pelaksanaan Pendidikan Karakter Di Sekolah Dasar. JURNAL KEPENDIDIKAN, Volume 43, Nomor 1, Mei 2013, Halaman 19 31. 2013.

[25] Light, G. and Cox, R. Learning \& teaching in higher education. London: Paul Chapman Publishing. 2001.

[26] Hartoyo. Penerapan Model Pembelajaran Kontekstual berbasis Kompetensi untuk Meningkatkan Efektifitas Pembelajaran. Jurnal Kependidikan Volume 39 Nomor 1 Mei 2009 hlm 67-78. 2009.

[27] Bouck, E.C. and Joshi, G. Functional Curriculum and students with mild intellectual disability. Exploring postschool outcomes through NLTS2, Education and Training in Developmental Disabilities, 47, 139-153. 2012

[28] Hauser, Susan, dkk. Funtional Academics- A Curiculum for Students with Visual Impairment. Texas School for the Blind and Visually Impairmed. 1999

[29] Yuanita, Putri, dkk. The Effectiveness of Realistic Mathematics Education Approach: The role of Mathematic Representation as Mediator Between Mathematical Belief and Problem Solving. Juornal PLOS ONE | https://doi.org/10.1371/journal.pone.0204847 September 27, 20182 / 20. 2018.

[30] Subagya. Pengembangan Buku Siswa Audio Taktual (BSAT) Matematika SMP/Sederajat untuk Siswa Tunanetra. Disertasi UNY. Yogyakarta: Universitas Negeri Yogyakarta. 2019.

[31] Solso, R.L.et.al Psikologi Kognitif. Jakarta: Penerbit Erlangga. 2007.

[32] Brigitte Röder Auditory and Auditory-Tactile Processing in Congenitally Blind Humans. Journal Hearning Research 258 (2009) 165-174. Elsevier. 2009.

[33] Barraga, N. Social Learning Theory. Englewood Cliffs. N.J: Prentice Hall. 1976.

[34] Pujiati. Pengembangan Bahn Ajar Praktikum Pengantar Akuntansi.Jurnal. Jurnal Ekonomi dan Pendidikan Vol 4 No.2, 2007.

[35] Palupi, D.T. Cara mudah memahami Kurikulum. Surabaya: Jaring Pena. 2016.

[36] Suparman, Atwi. Desain Instruksional Modern, Panduan Para Pengajar dan Inovator Pendidikan Edisi Keempat. Jakarta: Erlangga. 2014.

[37] Supriyadi. Developing Teaching Materials of Writing Scientific Paper Using Constructvision Approach. Jurnal. Journal of Education and Practice, Vol.4, No.24: 34-42. . 2013.

[38] Ronghua, J \& Stanley, O.N. Theories and Research in Educational Technology and Distance Learning Instruction Through Blackboard. Jurnal. Universal Journal of Educational Research, Vol.2 (2): 161172. 2014

[39] Dar, F. Textbook Materials and Their Succesfull Application in The Classroom: Implication for Language Development. Jurnal. Journal of Educational and Instructional Studies in the World, Volume 2, issue 4: 109-114. 2012

[40] Harjanto. Perencanaan Pengajaran. Jakarta: Rineka Cipta. 2011. 